\title{
FANCB Gene Mutation
}

National Cancer Institute

\section{Source}

National Cancer Institute. FANCB Gene Mutation. NCI Thesaurus. Code C156022.

A change in the nucleotide sequence of the FANCB gene. 